\title{
RECONNAISSANCE OF POLYCHLORINATED BIPHENYLS IN THE ARKANSAS RIVER BETWEEN MUSKOGEE AND WEBBERS FALLS LOCK AND DAM, OKLAHOMA
}

OPEN-FILE REPORT $80-216$

Prepared in cooperation with the OKLAHOMA WATER RESOURCES BOARD 

Conversion factors.............................. iv

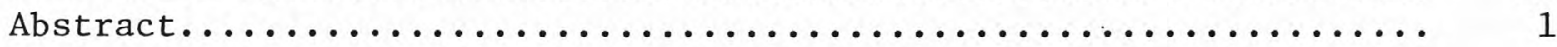

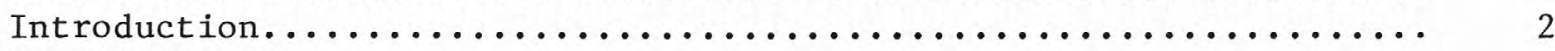

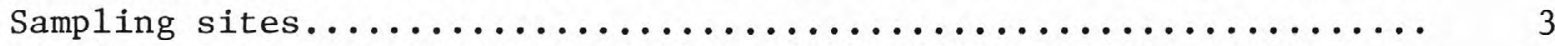

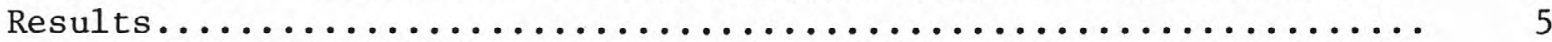

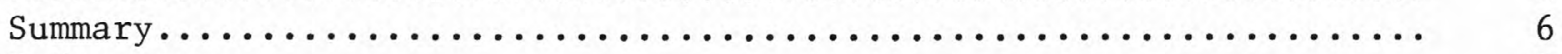

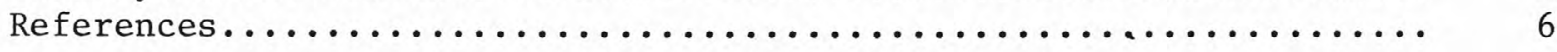

\section{ILLUSTRATIONS}

Figure 1.--Map of the study area showing locations of cross sections sampled.

TABLES

Table 1.--PCB concentrations in bottom material between Muskogee and

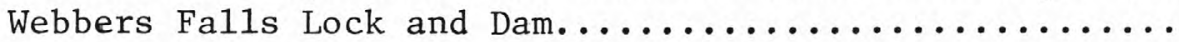




\section{CONVERSION FACTORS}

English units used in this report may be converted to metric units by the following conversion factors:

Multiply English Unit

foot (ft)

mile (mi) by

.3058

1.609 to obtain Metric unit meter (m)

kilometer $(\mathrm{km})$ 
Analysis of samples collected from the Arkansas River between Muskogee and Webbers Falls Lock and Dam, Oklahoma, in November 1978 showed that concentrations of polychlorinated biphenyls in the dissolved and suspended phases were less than the detection limit of 0.1 micrograms per liter. The maximum polychlorinated biphenyl concentration measured in samples of the bottom material was 16 micrograms per kilogram and occurred 5.9 miles below the U.S. Highway 62 bridge in Muskogee. 
Polychlorinated bipheny1s, which are toxic to both man and aquatic life, have a wide variety of industrial uses. The area in and around Muskogee, Oklahoma, has been rapidly industrializing due to the re1atively mild climate, the available work force, the availability of power, and access to world ports through the Kerr-McClellen Arkansas River Navigation System. Because of this industrialization and the possible attendant use of PCBs (polychlorinated biphenyls) the Oklahoma Water Resources Board is concerned that the concentration of PCBs in the reach of the Arkansas River near Muskogee could exceed the State Watèr Quality Standards (Oklahoma Water Resources Board, 1977). Compliance with the State Water Quality Standards for PCBs is based upon the ambient concentrations of PCBs. An increase in PCBs to concentrations greater than the concentration established as ambient would constitute a violation of the State Water Quality Standards. 
Cross-sections numbered from 1 through 8 on figure 1 were sampled in November 1978. Six of the cross-sections were in the reach of the Arkansas River from Muskogee to Webbers Falls Lock and Dam. Each of the two major tributaries, the Neosho and Verdigris Rivers, which enter the Arkansas River near Muskogee, Oklahoma, was sampled at a cross-section near the mouth. The daymark inland navigation marker references given in the following list are from the Corps of Engineers navigation charts for that reach of the Arkansas River (U.S. Army Corps of Engineers, 1976). The cross-sections that were sampled are as follows:

1. Arkansas River at State Hwy 16 Bridge, near Muskogee, Oklahoma.

2. Verdigris River at Wybark Daymark, near Wybark, Oklahoma.

3. Neosho River 0.5 mile above the mouth, near Muskogee, Oklahoma.

4. Arkansas River at Riverside Daymark, near Muskogee, Oklahoma.

5. Arkansas River at Beverly. Daymark near Muskogee, Oklahoma.

6. Arkansas River at Hopewe11 Daymark, near Braggs, Oklahoma.

7. Arkansas River at Elm Grove Daymark, near Braggs, Oklahoma.

8. Arkansas River at Sulphur Creek Daymark, near Braggs, Oklahoma.

At each cross section, three depth integrated samples of the watersediment mixture were taken at approximately 25,50 and 75 percent of the width. At each cross-section samples of the bottom material were taken at approximately 33 and 67 percent of the width. 


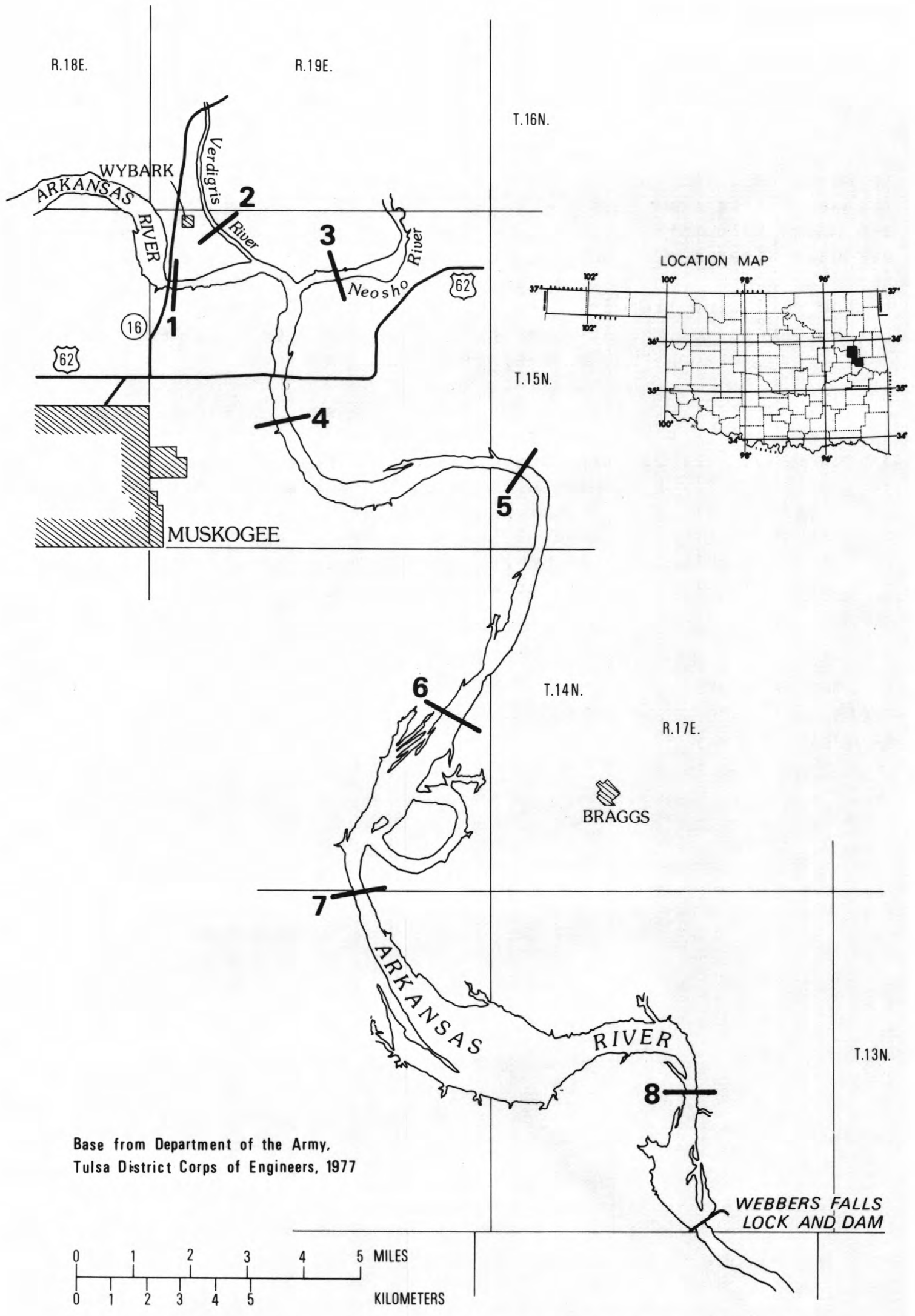

Figure 1.--Locations of the cross-sections sampled (numbered 1-8). 
The water-sediment mixture samples from each quarter point from each cross-section were analyzed for the following PCB arochlors; Arochlor 1016, Arochlor 1221, Arochlor 1232, Arochlor 1242, Arochlor 1248, Arochlor 1254, and Arochlor 1260. In each sample of the water column, the suspended and dissolved PCB arochlors were less than the detectable limit which was $0.1 \mathrm{ug} / \mathrm{L}$ (micrograms per liter).

The results of the analyses of the bottom material are given in table 1. The concentrations shown in the table are for total PCBs in the bottom material and do not differentiate between the various arochlors. The detectable limit for PCBs in bottom material is $1 \mathrm{ug} / \mathrm{kg}$ (micrograms per kilogram). Values given in table 1 as $0 \mathrm{ug} / \mathrm{kg}$ are therefore concentrations less than the detectable limit. PCB concentrations were highest, 13 to $16 \mathrm{ug} / \mathrm{kg}$, in the area between the Beverly Daymark, crosssection 5, and the Hopewell Daymark, cross-section 6. PCBs were found in the bottom material near the mouth of the Neosho River. One of the Neosho River bottom samples was lost in shipment and, therefore, corroboration of the level of concentration of PCBs at this cross-section was not possible.

Table 1.--PCB concentrations in bottom material between Muskogee and Webbers Falls Lock and Dam [Concentrations are in micrograms per kilogram]

\begin{tabular}{ccc}
$\begin{array}{c}\text { Cross Section } \\
\text { Number }\end{array}$ & $\begin{array}{l}\text { Percent of distance } \\
\text { from right bank }\end{array}$ \\
\hline 1 & 03 & 67 \\
2 & 0 & 0 \\
3 & -- & 5 \\
4 & 1 & 0 \\
5 & 7 & 16 \\
6 & 13 & 8 \\
7 & 4 & 6 \\
8 & 4 & 3
\end{tabular}


Concentrations of dissolved and suspended PCBs in the Arkansas River between Muskogee and Webbers Falls Lock and Dam during a reconnaissance in November 1978 were less than $0.1 \mathrm{ug} / \mathrm{L}$. The concentration of PCBs in the bottom material increased downstream from Muskogee and was highest ( 13 to $16 \mathrm{ug} / \mathrm{kg}$ ) in the vicinity of cross-sections 5 and 6 . Downstream from cross-section 6, the concentration of PCBs decreased to about $4 \mathrm{ug} / \mathrm{kg}$. $\mathrm{PCB}$ concentrations of about $5 \mathrm{ug} / \mathrm{kg}$ was found near the mouth of the Neosho River.

\section{REFERENCES}

Oklahoma Water Resources Board, 1977, Ok1ahoma's Water Quality Standards, 1976, Publication 79, 103 p.

U.S. Army Corps of Engineers, 1976, Navigation charts McClellen-Kerr Arkansas River Navigation System, Catoosa, Oklahoma to Mouth White River, 15 sheets, 63 charts. 
